\title{
Peran pelatihan desain grafis dalam mewujudkan pemuda rentan yang memiliki keterampilan dan kemandirian
}

\author{
Febrina Sari@*, Tri Handayani, \& Soni Fajar Mahmud \\ Sekolah Tinggi Teknologi Dumai \\ * febri_ghaniya@yahoo.co.id
}

\begin{abstract}
Abstrak. Anak putus sekolah merupakan Pemuda Rentan yang biasanya menghabiskan hari-hari mereka dengan nongkrong di pinggir jalan atau di persimpangan jalan serta di pos ronda, hal ini karena mereka masih belum produktif (belum bekerja). Sebagian dari pemuda rentan ada yang sudah bekerja namun hanya sebagai buruh kasar dengan upah sebesar 40-60 ribu rupiah per hari, dibandingkan dengan Desa lainnya anak putus sekolah/pemuda rentan di Desa Bukit Kayu Kapur memiliki persentase yang lebih tinggi yaitu mencapai 7\%, yakni sebanyak 114 jiwa, dari total jumlah penduduk produktif sebanyak 1630 jiwa. Hal ini dikarenakan Pemuda Rentan tidak memiliki pengetahuan dan keterampilan khusus untuk dapat bekerja dan memperoleh upah yang lebih baik.Telah dilaksanakan kegiatan Program Kemitraan Masyarakat Stimulus dalam upaya pemberdayaan pemuda rentan/anak-anak putus sekolah guna mengurangi jumlah penganguran yang tidak memiliki ketrampilan. Upaya yang dilakukan adalah dengan memberikan pelatihan desain grafis kepada pemuda rentan. Hasil yang telah dicapai dalam kegiatan Program Kemitraan Stimulus ini adalah meningkatnya pengetahuan anggota kelompok pemuda rentan tentang penggunaan komputer dan pemuda rentan telah memiliki keterampilan dalam mendesain beberapa produk seperti spanduk, banner, kartu nama, undangan, kalender dan brosur.
\end{abstract}

Kata kunci: keterampilan; kemandirian; pelatihan; pemuda rentan

\begin{abstract}
Out-of-school children are Vulnerable Youth who usually spend their days hanging out on the roadside or at crossroads and at patrol posts, this is because they are still unproductive (not working). Some vulnerable youths have worked but only as unskilled laborers with wages of 40-60 thousand rupiah per day, compared to other villages, school dropouts/vulnerable young people in Bukit Kayu Kapur Village have a higher percentage of 7\%, which is 114 people, from the total productive population in 1630. This is because Vulnerable Youth do not have the specific knowledge and skills to be able work and get better wages. The Community Stimulus Partnership Program has been implemented in an effort to empower young people who are vulnerable to dropping out of school to reduce the number of unemployed people without skills. This effort is to provide graphic design training for vulnerable youth. The results that have been achieved in the Stimulus Partnership Program activities are the increased knowledge of members of vulnerable youth groups about the use of computers and vulnerable youth who have skills in designing several products such as banners, banners, business cards, invitations, calendars and brochures.
\end{abstract}

Keywords: independence; skills; training; vulnerable youth

To cite this article: Sari, F., T. Handayani, \& S. F. Mahmud. 2019. Peran pelatihan desain grafis dalam mewujudkan pemuda rentan yang memiliki keterampilan dan kemandirian. Unri Conference Series: Community Engagement 1: 493-498 https://doi.org/10.31258/unricsce.1.493-498

(C) 2019 Authors

Peer-review under responsibility of the organizing committee of Seminar Nasional Pemberdayaan Masyarakat 2019 


\section{PENDAHULUAN}

Desa Bukit Kayu Kapur merupakan salah satu desa yang terletak di wilayah Kecamatan Bukit Kapur Kota Dumai Provinsi Riau dengan pertumbuhan perekonomian yang rendah. Profesi masyarakatnya rata-rata sebagai petani, buruh tani dan buruh bangunan, sehingga tingkat kesejahteraan masyarakat relatif rendah. Hal ini mengakibatkan banyak anak yang putus sekolah, umumnya hanya mampu menempuh pendidikan sampai jenjang SMP. Menurut data BPS Kota Dumai, lebih dari 65\% penduduk Kota Dumai berusia muda antara 1545 tahun yang merupakan penduduk usia produktif. Dari $65 \%$ tersebut $45 \%$ nya merupakan pemuda rentan/anak putus sekolah.

Desa Bukit Kayu Kapur merupakan salah satu desa yang ada di Kota Dumai dengan tingkat putus sekolahnya sangat tinggi hal ini berbanding lurus dan jumlah pengangguran yang tinggi pula, jika dibandingkan dengan Desa-Desa lainnya anak putus sekolah di Desa Bukit Kayu Kapur memiliki persentase yang lebih tinggi yaitu mencapai 7\%, yakni sebanyak 114 jiwa, dari total jumlah penduduk produktif sebanyak 1630 jiwa.

Anak putus sekolah merupakan pemuda rentan (Sutopo, 2014) yang biasanya menghabiskan hari-hari mereka dengan nongkrong di pinggir jalan atau di persimpangan jalan serta di Pos Ronda, Pada kondisi ini, anak putus sekolah menjadi rentan untuk terlibat pada kasus-kasus kriminalitas akibat pengaruh kekuatan yang tidak baik dalam lingkungan sosialnya, seperti resiko pemakaian obat terlarang, kekerasan atau kegiatan seksual yang tidak aman, pemuda rentan yaitu pemuda yang mudah terkena pengaruh negatif dari luar yang karena satu dan lain hal. Hal ini terlihat dari masih didapati kasus-kasus pemuda rentan yang melakukan berbagai tindak kriminalitas yang intensitasnya masih tergolong sering. Pada situs Pekanbaru Tribun (2017) sejumlah pemuda yang terlibat tauran di kota Dumai tak kunjung jera, ada dari pemuda tersebut sudah dua kali berurusan dengan polisi. Mereka tetap terlibat aksi yang meresahkan masyarakat. Berikut gambar cuplikan beritanya.

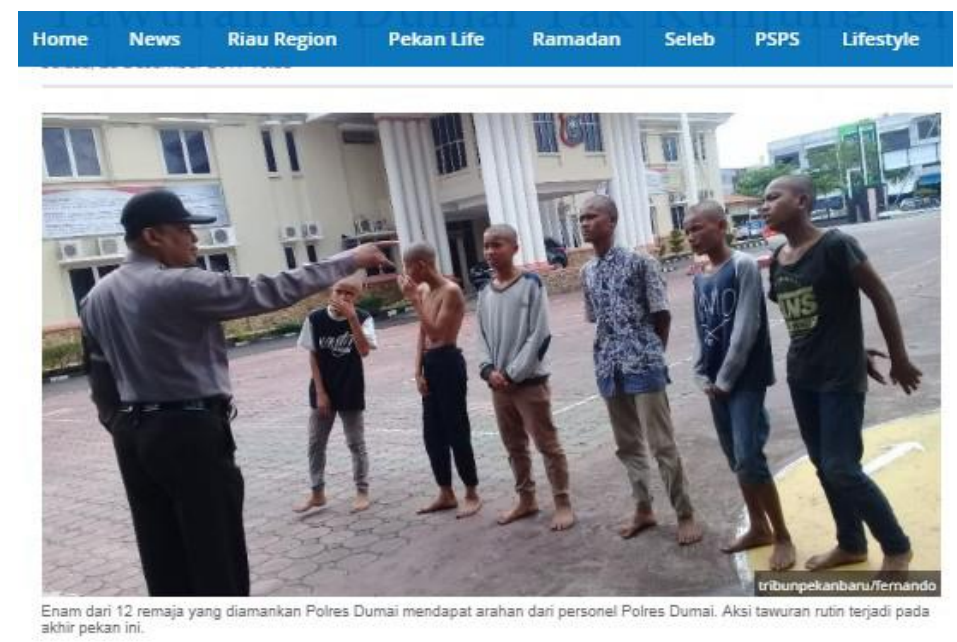

Gambar 1. Pemuda yang terlibat tauran diamankan Polres Dumai

\section{MASALAH}

Pemuda rentan yang tidak memiliki skill merupakan salah satu penyebab tingginya tingkat kriminalitas/Kejahatan di Desa Bukit Kayu Kapur Kota Dumai, pada situs Koran MX (2018). Satuan Reserse kriminal Polres Dumai berhasil mengungkap jaringan komplotan kejahatan spesialis jambret yang beranggotakan 7 orang ini, 2 diantaranya merupakan warga Kecamatan Bukit Kapur kota Dumai, yang berusia 20 dan 23 tahun.

Berdasarkan analisis situasi dan survei serta wawancara Tim Pengusul dengan Kepala Desa, Jumlah pemuda rentan/Putus Sekolah mencapai 7\% dari jumlah penduduk desa Bukit Kayu Kapur. Pemuda rentan tersebut pendidikannya rata-rata adalah SD dan SMP, Usia mereka bervariasi antara 15 tahun sampai dengan 35 tahun. Hampir 45\% dari pemuda rentan tersebut berstatus pengangguran dan selebihnya bekerja sebagai buruh tani, sebagai buruh bangunan yang nota bene pekerjaanya sangat berat yaitu sampai dengan 40 jam kerja seminggu, dengan upah sebesar 40-60 ribu rupiah per hari. Pemuda rentan tidak memiliki skill atau 
keterampilan khusus, hal ini merupakan salah satu penyebab pemuda rantan tidak dapat bekerja dan memperoleh upah yang lebih baik. demikian juga mereka yang bekerja sebagai buruh perkebunan sawit.

Kesepakatan antara tim pengusul dengan kelompok pemuda rentan melalui ketua karang taruna, potensi yang akan dirintis adalah mengembangkan ketrampilan pemuda rentan sehingga mereka mempunyai Pengetahuan dan keterampilan dalam bidang Desain Grafis. Hal ini didasari pada bahwa kebutuhan akan adanya jasa Desain Grafis yang semakin meningkat dalam kehidupan masyarakat sekarang ini, seperti dalam menyelenggarakan acara pernikahan, syukuran, promosi sekolah / kampus dan penyelenggaraan kegiatan yang diadakan oleh instansi baik negeri maupun swasta yang frekuensinya sangat sering sekali dilakukan di masyarakat dan kegiatan ini membutuhkan atribut seperti undangan dan spanduk untuk menunjang pelaksanaan kegiatan. Berdasarkan uraian di atas, maka mitra perlu dibekali keterampilan melalui pelatihan Desain Grafis khususnya mendesain iklan, spanduk, baliho, undangan, brosur, kartu nama, banner, kalender dengan konten dua dimensi (2D).

Tujuan Kegiatan Program Kemitraan Masyarakat Stimulus yang dilakukan pada kelompok pemuda rentan yakni dengan melakukan pelatihan Desain Grafis, adalah untuk meningkatkan Pengetahuan (soft skill) dan Keterampilan (life skill) pemuda rentan dalam pemanfaatan teknologi komputer khususnya penggunaan aplikasi desain grafis. Sehingga pemuda rentan dapat memperoleh pekerjaan dan upah yang lebih baik dari sebelumnya.

\section{METODE PENERAPAN}

Metode pelaksanaan untuk mengatasi permasalahan yang dihadapi mitra adalah metode demonstrasi dan pelatihan. Hal ini telah disepakati dengan pihak mitra

1. Melakukan pendekatan kepada Kepala Desa Bukit Kayu Kapur untuk mensinergikan kegiatankegiatan yang akan dilakukan dalam program pemerintah desa khususnya yang berkaitan dengan permasalahan untuk pemberdayaan pada kelompok pemuda rentan yaitu kelompok Laksamana. Solusi yang ditawarkan adalah melalui pelatihan desain grafis yang dapat meningkatkan ketrampilan bagi pemuda rentan sehingga dapat mandiri dalam kehidupan sosial kemasyarakatnya (Tejo, 2004) dan mendapatkan pekerjaan yang lebih layak.

2. Metode pendekatan yang dilakukan adalah dengan mengadakan pertemuan dengan anggota kelompok "Laksamana" untuk menyampaikan program dan mengajak semua anggota kelompok untuk bersamasama aktif merealisasikan program kegiatan pelatihan.

3. Partisipasi mitra yaitu kelompok Laksamana ditunjukkan dengan adanya dukungan dan kesanggupan untuk bekerjasama sebagai mitra dengan Tim pengusul dari Sekolah Tinggi Teknologi Dumai dalam penerapan Program Kemitraan Masyarakat. Partisipasi mitra ini juga ditunjukkan melalui pelaksanaan kegiatan secara bersama-sama dalam hal kesediaan mengikuti pelatihan dan penetapan lokasi pelatihan. Kegiatan ini dilakukan melalui pertemuan dan pelatihan dengan anggota kelompok Laksamana dalam bentuk kegiatan diklat.

Rencana kegiatan yang akan dilakukan dalam pemberdayaan pemuda rentan (putus sekolah) yaitu terhadap anggota kelompok Laksamana ini, mengikuti aktivitas pelaksanaan penelitian tindakan yang terdiri dari persiapan, pelaksanaan, observasi, evaluasi, pendampingan dan refleksi maka ditetapkan rincian tahapan kegiatan sebagai berikut:

1. Tahap Persiapan, tahap ini dilakukan meliputi:

a. Survei, pemantapan dan penentuan lokasi, sasaran serta penentuan permasalahan yang dihadapi oleh mitra.

b. Evaluasi permasalahan dan penentuan solusi yang ditawarkan dan disepakati bersama mitra.

c. Penyusunan materi dan kelengkapan kegiatan.

2. Tahap pelaksanaan diklat dan pelatihan, meliputi:

a. Pelatihan Dasar Komputer

b. Pelatihan menggunakan aplikasi Corel Draw untuk membuat product percetakan (desain undangan, kartu nama, kop surat, spanduk dan lain-lain)

c. Pelatihan menggunakan aplikasi Adobe Photoshop dan Adobe Ilustrator untuk mengolah data gambar

3. Tahap Evaluasi Evaluasi pelaksanaan program akan dilakukan berdasarkan hasil monitoring yang dilakukan dengan cara memantau kegiatan secara berkala mulai dari kegiatan pelatihan, dengan 
melakukan penilaian terhadap kegiatan yang sudah dilakukan, serta memberikan saran/rekomendasi untuk perbaikan/penyelesaian masalah yang mungkin timbul, agar secara keseluruhan dari kegiatan ini dapat dicapai dengan baik.

\section{HASIL DAN KETERCAPAIAN SASARAN}

Kegiatan pelatihan Desai Grafis dilaksanakan selama 4 bulan mulai dari bulan April sampai bulan Juli 2019, dengan berpedoman pada kerangka kegiatan PKMS yang telah dirancang dan disepakati bersama. Pelatihan dilakukan di laboratorium Sekolah Tinggi Teknologi (STT) Dumai. Hasil yang sudah dicapai dalam kegiatan PKMS ini adalah sebagai berikut:

\section{Pelatihan Dasar Komputer}

Partisipasi mitra yaitu kelompok Pemuda Rentan "Laksamana" ditunjukkan dengan adanya dukungan dan kesanggupan untuk bekerjasama sebagai mitra dengan Tim pengusul dari Sekolah Tinggi Teknologi Dumai dalam penerapan Program Kemitraan Masyarakat. Partisipasi mitra ini juga ditunjukkan melalui pelaksanaan kegiatan secara bersama-sama dalam hal kesediaan mengikuti pelatihan di lokasi pelatihan yang telah disepakati gambar 4 menunjukkan partisipasi dan kesunguhan mitra sebagai peserta.

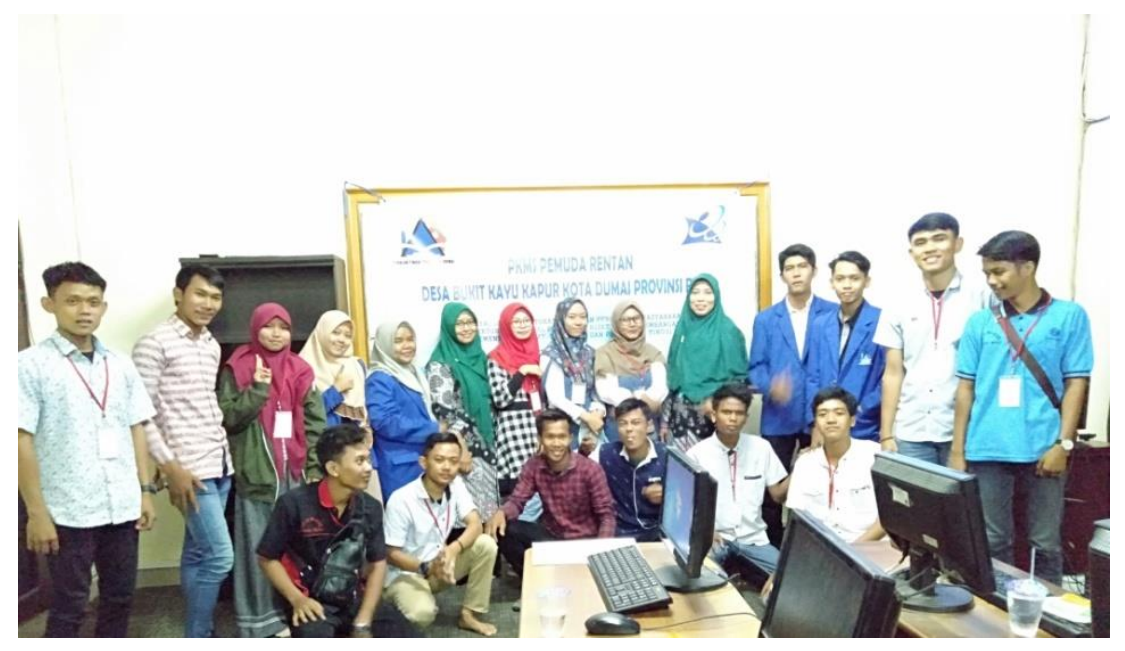

Gambar 3. Peserta pelatihan desain grafis

Kegiatan pelatihan diawali dengan keterampilan dasar komputer meliputi pengenalan dan pengoperasian perangkat komputer serta pelatihan Microsoft Word. berdasarkan kesepakatan bersama mitra pelatihan akan diadakan setiap hari senin hingga jumat yang dimulai dari jam 13.00 sampai dengan 16.00 WIB. Pelatihan dasar komputer ini dilaksanakan dalam rentang waktu 2 hari, selama pelatihan berlangsung $75 \%$ dari peserta sudah mampu mengoperasikan komputer dan menggunakan Ms Word sebagai aplikasi pengolah kata, materi yang disampaikan berdasarkan hasil evaluasi menunjukkan pererta pelatihan mampu memodifikasi teks seperti merubah warna dan jenis/type teks, peserta juga telah mampu menginsert dan edit gambar, hal ini akan menjadi modal dasar bagi peserta untuk melanjutkan ke pelatihan Desain Grafis.

\section{Pelatihan Desain Grafis}

Kegiatan berikutnya dilanjutkan dengan pelatihan inti yakni Desain Grafis dimulai dari pengenalan beberapa aplikasi yang dapat sering digunakan untuk melakukan desain grafis yakni Corel Draw, Adobe Photoshop dan Adobe Ilustrator. Untuk desain grafis Pelatihan dilaksanakan dalam rentang waktu 10 hari kerja pada jan 13.00 sampai dengan jam 16.00, peserta sangat antusias dalam mengikuti pelatihan hal ini terlihat dari keseriusan para peserta dalam mengerjakankan latihan yang ada pada modul pratikum. Gambar 5 menunjukkan aktifitas pelatihan desain grafis. 

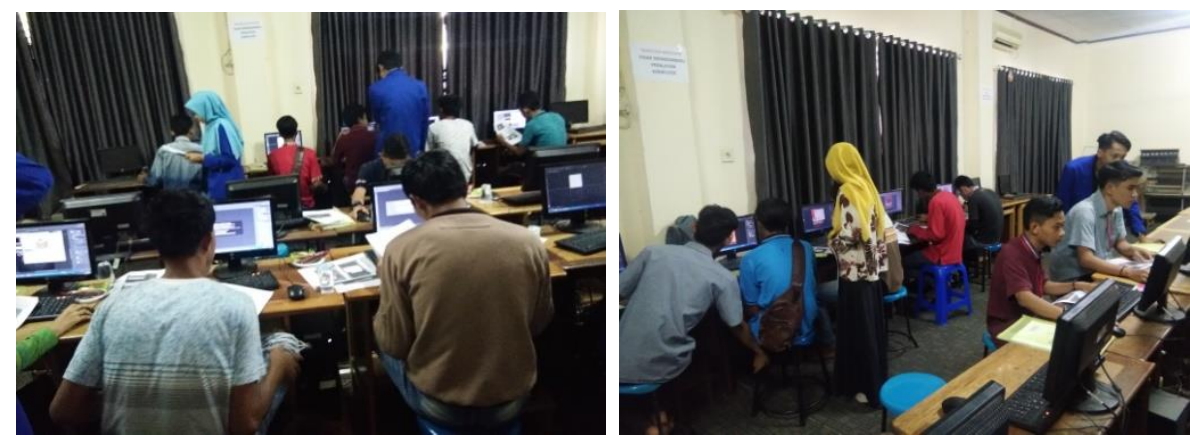

Gambar 4. Kegiatan pelatihan

Gambar berikut ini menunjukkan pelatihan yang dilaksanakan dapat meningkatkan pengetahuan dan keterampilan para peserta pelatihan dalam menggunakan Aplikasi Desain Grafis, peserta dapat mendesain brosur, spanduk, kartu nama dan undangan, serta beberapa produk lainnya. Hal ini tentunya sangat membantu para peserta yang merupakan pemuda rentan, memiliki bekal untuk membuka peluang usaha (Buchari, 2010).
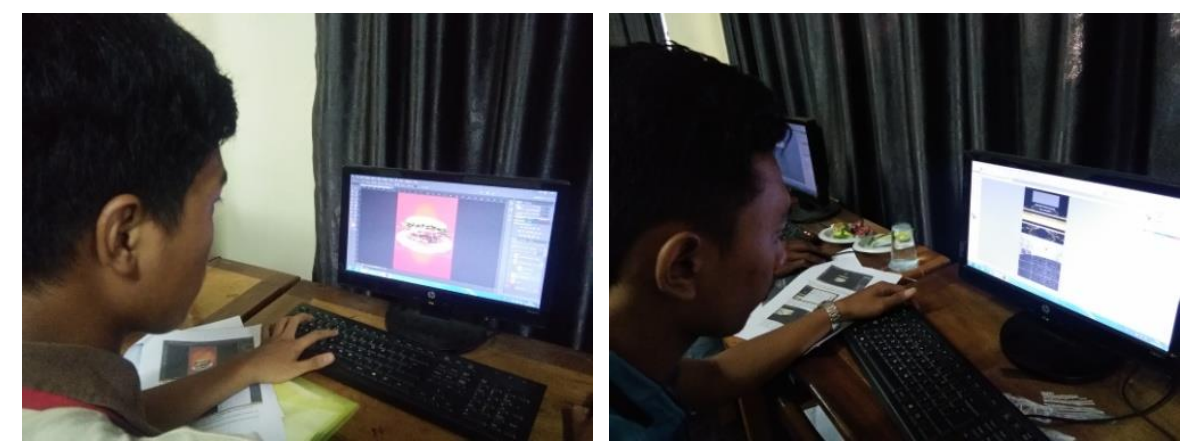

Gambar 5. Hasil desain peserta berupa brosur dan undangan

Desain Grafis merupakan bekal keterampilan yang cukup mudah untuk dipelajari dan dipraktekkan, para peserta mesti memiliki kemauan, ketelitian dan harus berani mempadu padankan warna untuk menghasilkan produk grafis yang unik dan menarik. Kepada para peserta pelatihan jugadiberikan keterampilan tentang tata letak desain gambar (Hidayatullah, 2008).

\section{KESIMPULAN}

Program Kemitraan Masyarakat Stimulus yang telah dilaksanakan dapat meningkatkan pengetahuan dan keterampilan pemuda rentan dalam menggunakan aplikasi desain grafis, hal ini dapat dilihat dari kemampuan para pemuda rentan yang telah dapat mengoperasikan komputer dan mampu mendesain berbagai produk grafis 2D seperti membuat undangan, brosur, kop surat, kartu nama, spanduk, baliho, banner, kalender, poster dan buletin.

\section{UCAPAN TERIMAKASIH}

Ucapan terimakasih disampaikan kepada Direktorat Riset dan Pengabdian kepada Masyarakat Kemenristek Dikti yang telah memberikan dana kegiatan pengabdian kepada masyarakat melalui Program Kemitraan Masyarakat Stimulis (PKMS) untuk pendanaan 2018.

\section{DAFTAR PUSTAKA}

Alam, B. 2010. Kewirausahaan (edisi revisi). Bandung: CV Alfabeta.

Hidayatullah, T. 2008. Lengkap dan Cepat Membuat Desain dengan CorelDraw MX4. 
Koran MX. 2018. Kawanan jambret diringkus buser. http://koranmx.com/baca/577/7-kawanan-jambret-diringkusbuser.html. Diakses pada 5 Februari 2018.

Nurseto, T. 2004. Menumbuhkan Wirausaha Kecil Menengah yang Tangguh. Jurnal Ekonomi \& Pendidikan 1(1).

Pekanbaru Tribun. 2017. Berulang kali ditangkap pemuda tawuran di Dumai tak kunjung jera. http://pekanbaru.tribunnews.com/2017/12/26/berulang-kali-ditangkap-pemuda-tawuran-di-dumai-tak-kunjungjera. Diakses pada 26 Desember 2017.

Sutopo, R. Oki, \& M. N. H. Pratma. 2014. Transisi Pemuda dalam Masyarakat risiko antara aspirasi hambatan dan ketidakpastian. Jurnal Universitas Paramadina 11. 